\title{
Corporate Social Responsibility Practices in Listed Companies
}

\author{
Helen Wong \\ The Hong Kong Polytechnic University \\ Hong Kong Community College, Hong Kong \\ Raymond Wong \\ The Chinese University of Hong Kong \\ School of Accountancy, Hong Kong
}

Received: Jan.14, 2015

Accepted: Jan. 29, 2015 Published: January 29, 2015

doi:10.5296/jmr.v7i1.6910

URL: http://dx.doi.org/10.5296/jmr.v7i1.6910

\begin{abstract}
Business ethics is a contemporary issue in nowadays business, it involves application of standards of moral behavior to business situations. To general public, apart from business ethics, they also concern whether corporations are operating socially responsible nowadays. Although one of the key objectives of a business corporation is to earn maximum profits for shareholders or owners, it is expected to conduct its operations in a manner to fulfill its social obligations. Big corporations are expected to have more corporate social responsibility practices because they have more resources. This study is to examine the current practices of corporate social responsibility in three Hong Kong Blue Chip companies. The selected companies are ranked top three in an Oxfam Hong Kong Survey 2009. Similarities and differences of their practices are discussed in the study. The analysis provides insights to other companies in taking up the corporate social responsibility, such as resources allocation and action plan towards better community and environment etc. Furthermore, government or stock exchange can also take it as a reference for setting rules and practices for companies.
\end{abstract}

Keywords: Business ethics, Corporate social responsibility, Listed companies 


\section{Introduction}

Ethics is originated in the area of philosophy. Business ethics is a form of applied ethics that examines ethical rules and principles within a business context, the various moral or ethical problems that arise in business community, and special duties or obligations that apply to persons in business setting (Christensen et al., 2007). Although the primary objective of business is to earn maximum profits for shareholders or owners in ethical way, it is also expected to operate in a way that fulfills social obligation. Companies have corporate social responsibility (CSR) practices commit themselves operating in a way to benefit the community at large (Olivia, 2011). Businesses nowadays are expected to operate ethically and in a way fulfilling social obligations. This study concentrates on examining CSR practices of business because CSR involves doing good to different stakeholders, not just shareholders, which is a more comprehensive approach in companies' strategies.

\section{Literature Review}

The initial period for the emergence of CSR belief is in around 1920s (Hoffman, 2007). At that time, business started to be expected to possess social responsibility rather than an individual. In the early development, many take an instrumental approach to CSR. The most famous advocate is Milton Friedman. Friedman (1962) argues that it would be unethical for the company to do anything other than deliver profits to the investors of the company. Friedman also argues that the manager, as an employee of the company, has an ethical obligation to fulfill his role in achieving the expectations of his employers. The instrumental perspective states that the only obligation of a company is to maximize profits for its shareholders in providing goods and services which meet customers' needs (Ghillyer, 2014).

Until 1980s, the emerging of stakeholder theory states business has to concern both internal and external stakeholders (Freeman, 1984). The stakeholder theory emphasizes that both shareholders and all stakeholders' interests should haveequal importance. The social contract approach states a company has an obligation to society over and above the expectations of its shareholders (Ghillyer, 2014). The modern social contract approach argues that as the company depends on society for its existence and growth, the company has obligation to the society rather than just to shareholders. Company has to recognize the needs of all stakeholders (including customers, employees, shareholders, vendor partners and community partners etc.) rather than just shareholders. Nowadays, CSR is generally defined as the actions of a company aim at achieving social benefits over and above maximizing profits for its shareholders and meeting legal obligations.

Different companies may have different level and form of CSR. There are three distinct types of CSR - ethical, altruistic, and strategic (Ghillyer, 2014). Ethical CSR is the purest form of CSR in which the company pursues a defined sense of social conscience in managing its financial responsibility to shareholders, legal obligation to the society, and its ethical responsibility to do right things for its stakeholders. Altruistic CSR is a philanthropic form of CSR in which the company has specific initiatives to give back to the company's community or country, for example, giving donation to needed. Strategic CSR is also a philanthropic approach to CSR in which company's action will generate the most positive publicity or 
goodwill for the company while it also runs the greatest risk of being perceived as self-serving behavior on the part of the company. For instance, Ford Motor spent millions on an advertising campaign to raise awareness of the need for booster seats for children over 40 pounds and under 4 feet 9 inches and gave away a million seats as part of the campaign. Such booster seat campaign can be considered as a way to position Ford as the auto manufacturer that cares about safety of its passengers and drivers (Ghillyer, 2014).

\section{Benefits \& Costs of having CSR}

Proponents of CSR argue that company can benefit from having CSR, such as enhancing reputation, generating greater employee and customer loyalty and retention (Lance, 2001). Firstly, CSR can generate reputation and then create business value to the social responsible company (Bebbington et al., 2008). CSR can maintain customer loyalty which is important for company because it is more costly to attract new customers than to retain existing customers (Mandhachitara \& Poolthong, 2011). Secondly, adopting CSR can make company more profitable. Company can increase sales revenue by gaining customer support and reduce cost by having environmental friendly approach in production. More tax reduction will be obtained by using environmental friendly machinery or making charitable donations (Doukakis et al., 2005). Having environmental-friendly production can also achieve cost efficiency position (Gyves \& Higgins, 2008). Thirdly, CSR has positive impact on strategic decision of the company. CSR facilitates product differentiation strategy to be successful and a higher price can be charged for the product (Cruz \& Boehe, 2008). For instance, differentiating through the use of CSR resources like recycled products or organic pest control (McWilliams \& Siegel, 2001). Company can also gain competitive advantage since the company shows the uniqueness of the value to community (Holme, 2010).

However, implementing CSR is not without costs. Firstly, using new machinery in production will involve intensive capital investment which may then result in liquidity problem (Yeoh, 2007). Higher capital cost may shake the position of cost leadership of the company (Lanoizelee, 2011). Secondly, company may hire additional staff to advocate and conduct CSR through affirmative action, community outreach, and improved labour relations (McWilliams \& Siegel, 2001), therefore higher wages and benefits have to be provided. Thirdly, CSR may require higher cost of materials or inputs from suppliers. For instance, Body Shop purchases special ingredients and formulas that have not been animal tested (McWilliams \& Siegel, 2001).

\section{CSR Practices across Borders}

In Asia, the Chinese Government is also taking a proactive role in CSR. In 2008, the State Owned Assets Supervision and Administration Commission of the State Council released guiding principles for state-owned companies to implement CSR measures (OHK, 2010). In Hong Kong, the Hong Kong Stock Exchange first published the Environmental, Social and Governance Reporting Guide in 2012 as recommended practice for issuers with financial years ending after December 2012, and it is expected to be a regulatory requirement by 2015 (CLP, 2013). Listed companies are therefore expected to have CSR practices and report it annually to the public. In Japan, important standards that regulate the social obligations of 
companies and relate to their CSR activities include the commercial code, basic environment law, basic food safety law, and law guaranteeing equal opportunity and treatment of men and women on jobs (CSR Japan website).

The CSR statement of the Presidency of the European Union highlights that its member states should take a global lead and serve as good example on CSR when building markets, safeguarding the environment and ensuring human rights in workplace (OHK, 2010). In Germany, listed companies have been required to report on key non-financial indicators. In Denmark, a new law on CSR reporting has come into force in 2011. The Danish Government requires large Danish businesses to disclose CSR activities in their annual reports (Danish Government Centre, 2011).

Even some non-profit making organizations also promote the need of CSR, for instance Oxfam Hong Kong (OHK), an international development and relief agency working to reduce poverty and injustice, urged the government to rewrite the Companies Ordinance in 2010 advocating the necessity to increase companies' disclosure on non-financial information such as social and environmental performance (OHK, 2010). OHK believes both voluntary efforts and mandatory measures imposed by regulators will create and sustain the momentum of CSR in Hong Kong. OHK submitted a proposal to the Hong Kong Stock Exchange on environmental, social and governance reporting in 2012. In 2009, OHK also conducted a CSR survey on forty-two Hang Seng Index (HIS) constituent companies. The HSI companies were rated in six areas: CSR strategy and reporting, stakeholder engagement, workplace, environment performance, supply chain, and community investment (OHK, 2010). The survey results show that Hong Kong and Shanghai Banking Corporation (HSBC), China Light Power Holdings Limited (CLP) and China Mobile Limited (CM) were the top 3 in having CSR practices among the 42 HIS constituent companies. It is interesting to examine the similarities and differences in the practice of CSR among the top 3 companies which can provide insights to other companies in taking up CSR.

With the increasing importance and demand of CSR, it is worthwhile to have study on CSR practices. This study aims at investigating:

1. the 2013 current practices of CSR in the top 3 companies rated by OHK's 2009 CSR survey;

2. the similarities and differences in the 2013 practice of CSR among the top 3 companies rated by OHK's 2009 CSR survey;

3. resources implications on having CSR; and

4. insights provided to companies and regulators.

\section{Research Method and Analysis}

This study will examine secondary data collected from recent websites, annual reports, and sustainability reports of Oxfam Hong Kong, HSBC, CLP, and CM. The CSR practices of these 3 companies will be highlighted and compared. 


\section{Hong Kong \& Shanghai Banking Corporation (HSBC)}

HSBC believes that making profit is not the only concern of the company. To be a sustainable bank, HSBC provides customers with their required products and services, manages the impact the company has on society and environment, invests in the future of its employees and community. HSBC has put great efforts in four aspects: environmental efficiency, climate business, sustainability risk, and community investment. In regard to environmental efficiency, the bank's activities have impact on the environment such as its buildings and information technology systems. To provide services in an environmentally friendly way, the company works hard to reduce energy consumption, waste and $\mathrm{CO} 2$ emissions. For instance, reducing annual employee carbon emissions from 3.5 tonnes to 2.5 tonnes by 2020 , reducing annual energy consumption per employee by $1 \mathrm{MWh}$, recycling 100 percent of office and electronic waste, increasing self-generated electricity from 0 to 5 percent, increasing energy consumption from renewables from 24 percent to 40 percent, using Leadership in Energy and Environmental Design (LEED) buildings, promoting paperless banking by giving customers access to internet banking, and having sustainable travel by using video-conferencing and webinars. In 2013, HSBC trained an additional 255 senior managers as part of its Sustainability Leadership Programme, bringing the total number to 627 . Besides, more than 2,800 employees are trained and acted as ambassadors for climate change.

In the area of climate business, HSBC supported low-carbon transport solutions, renewable-energy projects and clean-tech businesses. It has been rated the number one company for integrated climate change by Thomson Extel awards for Pan-European investment research for the past three years. HSBC's projects are not just limited to a single place, for instance, it structured a project finance deal to fund a 49.5-megawatt wind farm in Jilin Province of China. It also structured finance arranger for Johannesburg's Rea Vaya Bus Rapid Transit Project, a low-polluted and high-speed bus network in Africa.

Regarding sustainability risk, HSBC takes into account adverse impact on local communities and environment when doing its business. HSBC identifies key sectors where such impacts are likely to arise and creates sector policy to guide the way it operate in these sectors. For instance, it has Forestry Policy, Agricultural Commodities Policy, Chemicals Industry Policy, Defence Equipment Sector Policy, Freshwater Infrastructure Policy, and Mining and Metals Sector Policy etc.

In the area of community investment, it includes education, environment, volunteering, and donation. On education side, HSBC raises environmental awareness and provides scholarship and financial literacy classes. On environment side, HSBC partners with environmental organizations to motivate actions and build awareness to help ensure future generations inherit a greener environment. Staff members of HSBC volunteer helping the elderly, the young, and the mentally-disabled, and providing mentorship to students and volunteer activities. HSBC has won the Champion of the Highest Service Hour Award organized by Social Welfare Department of Hong Kong for seventh time since 1998. The Award recognizes employee's volunteering work contributed to the community. HSBC also donates 
huge sum of money to variety of causes in Hong Kong and around the world. It establishes the Hong Kong Bank Foundation which manages HSBC's donations in Hong Kong and mainland China.

HSBC's CSR practices cover a wide range of activities and endeavors. It has been ranked number one in OHK's CSR survey in both 2008 and 2009 when OHK conducted survey in these two years.

\section{China Light Power Holdings Limited (CLP)}

CLP has got the first runner-up in OHK's 2008 and 2009 CSR survey. In CLP's 2013 Sustainability Report, it mentions that CLP aims at creating value for shareholders, employees and wider community. CLP needs to provide reliable and affordable energy to customers in a way that minimizes negative impacts on environment and community, complies with government policies, and allows for a return to its shareholders. The three key aspects of CSR in CLP are: environment, economic and social. Regarding environmental performance, CLP aims at moving towards zero emissions, moving towards a more sustainable rate of resource use and moving towards no net loss of biodiversity. For instance, many initiatives have been carried out to decrease water use and waste production, and biodiversity efforts conform to local regulations and comply with company's Environmental Impact Assessment Policy.

In regard to economic aspect, CLP aims at creating long-term shareholders return, adapt proactively to a changing business environment, and enhancing individual and organizational capability. For instance, opportunities for new energy efficiency products and services and more advanced generation technologies are pursued, and several staff training and succession planning initiatives are implemented.

In respect to social aspect, CLP aims at achieving zero injuries, supporting a healthy workforce, developing committed and motivated employees, meeting customer expectations, earning and maintaining community acceptance, and operating business ethically. For instance, numerous community engagement and healthy lifestyle and work life balance initiatives are organized, strictest quality and safety standards are adhered, and new customer care billing system is improved.

CLP obtained the 2013 Sustainability and Social Responsibility Reporting Award organized by the Hong Kong Institute of Certified Public Accountants, and 2013 was the third successive year that CLP has won this award. Moreover, CLP also got the 2013 Best Sustainability Reporting Award and Australia - Hong Kong Sustainability Reporting Award organized by the Hong Kong Management Association (HKMA) and the Australian Reporting Awards and HKMA respectively.

\section{China Mobile Limited (CM)}

CM, a mainland China-based company, has got the second runner-up in OHK's 2008 and 2009 CSR survey. Its strategy focuses on six areas: shareholders, partners, customers, employees, communities, and environment. For shareholders, CM creates values for them by 
pursuing an ethical and healthy way to develop, accelerating the transformation and constructing infrastructure, innovating $4 \mathrm{G}$ technologies and promoting $4 \mathrm{G}$ commercialization.

For CM's value chain partners, CM works with partners to spearhead the development of the TD value chain and build a responsible supply chain, support them in various ways such as capital, technology, training and exploring new business opportunities, and develop green solutions and eco-friendly technologies and products. For customers, CM provides optimized services that address customers' needs on network quality, information security, privacy protection, and tariff.

For employees, CM provides care, respect and career development support to staff. CM also guarantees occupational health and safety and implements the Employee Assistance Programme organizing leisure activities for staff.

Regarding communities, CM supports community development and helps vulnerable groups. For instance, CM provides training to principals, establishes China Mobile Libraries and multimedia classrooms in central and western parts of China, the China Mobile Heart Caring Campaign provides free screening to children in poverty and surgeries for children diagnosed with congenital heart diseases, and along with the China Mobile Charity Foundation, CM supports education development.

In regard to environment, $\mathrm{CM}$ strictly manages its environmental impact and develops solutions to address climate change. For instance, CM continuously implements the Green Action Plan achieving fully-operating energy conservation and emissions reduction, CM conducts green network, develops and promotes energy-saving technologies and applications.

Because of its great efforts, CM was listed in the Dow Jones Sustainability Indices for the sixth consecutive year in 2013, and its sustainability practice was recognized by the UN Global Compact as a Best Practice in China.

Having reviewed the current 2013 CSR practices of the top 3 listed companies, below is a summary listing the areas they specifically mentioned in their websites or sustainability reports (Table 1). 
Table 1. Areas of CSR which HSBC, CLP and CM specifically mentioned*

(for those items without * does not mean that they do not involve in)

\begin{tabular}{|l|l|l|l|}
\hline & $\underline{\text { HSBC }}$ & $\underline{\text { CLP }}$ & $\underline{\text { CM }}$ \\
\hline Environment & $*$ & $*$ & $*$ \\
\hline Climate & $*$ & $*$ & $*$ \\
\hline Sustainability & $*$ & & \\
\hline Economic & & $*$ & $*$ \\
\hline & & & \\
\hline Social / Community includes: & & & \\
\hline Employee & & $*$ & $*$ \\
\hline Education & $*$ & & $*$ \\
\hline Volunteering & $*$ & & $*$ \\
\hline Donation & $*$ & & \\
\hline Partners & & & $*$ \\
\hline Customers & & $*$ & $*$ \\
\hline
\end{tabular}

\section{Similarities and Differences}

Both 3 companies have specifically mentioned and carried out CSR practices in the area relating to environment, climate, and community. For environment, they work hard to reduce waste remissions and energy consumption, and use energy-saving technologies and systems. All 3 companies have mentioned their practices in protecting the environment, and CLP and $\mathrm{CM}$ get more discussion on it. It may be because their products and services involve more energy and emissions.

For climate, all 3 involve in renewable-energy projects, sustainable use of resources, and develop solutions to address climate change etc.

Regarding community, the 3 companies all involve in it in different key items with different emphasis: employee, education, volunteering, donation, partners, and customers. For CLP and $\mathrm{CM}$, they specifically mention their care and support to employees. This may be due to the industry nature of the two. The two companies require employees with high technical knowledge and skill, therefore it is difficult to hire experienced and well-qualified employees in their industries, namely, electricity and telecommunications. For CLP and CM, they also specifically mention that they aim at meeting customer expectations and needs. In community, both HSBC and CM have highlighted education and volunteer work for discussion. They provide scholarship, literacy classes, training to principals, or multimedia classrooms etc. They also provide volunteering help to elderly and young, or free screening and surgeries to children in poverty etc. For donation, HSBC has specifically mentioned that it donates huge sum of money to different parts of the world and has the Hong Kong Bank Foundation. For partners, CM has specifically mentioned it works closely with value chain partners in exploring new business opportunities and developing eco-friendly products etc. 
In respect to sustainability, only HSBC has highlighted it as a single key aspect for discussion. It is about the sector policy created by HSBC in guiding the way it operates in these sectors which may have impacts on environment. For economic performance, both CLP and CM have specifically mentioned it. Economic performance is about their care to shareholders, they create value and returns to shareholders by pursuing ethical and healthy way in developing their businesses.

\section{Conclusion and Recommendation}

Having examined the current CSR practices in the 3 listed companies, they in general put heavy focus in environment, climate, and society. These areas cover using energy-saving technologies, developing solution for better climate and environment, donations, volunteering work, care for employees and customers, providing education to needed etc. It is in general believed that companies with more assets or income can put more resources into CSR. However, it is interesting to note that the ranking of income before tax and total assets of these 3 listed companies do not exactly correspond to their ranking in Oxfam Hong Kong's CSR 2009 survey result. Based on recent 2013 annual reports (Table 2), HSBC is not the top in both earning income before tax and having total assets among the three. CM gets the highest income before tax among the three and HSBC gets the highest total assets among the three. CLP gets the least in both income before tax and total assets among the three, however, CLP is the first-runner up in the survey. CLP's total assets and income before tax are far behind that of HSBC and CM. Therefore, the amount of income before tax and total assets may not be the only determinants of having successful CSR practices. Such phenomenon provides good examples for other companies which engaged or want to engage in CSR practices. It may be a matter of determination and companies care for the whole community and society and all stakeholders. Interested companies may start from small CSR practices, put resources on some easily achievable CSR practices initially, such as providing donations, scholarships, volunteering work and using less paper, and then expands to larger perspectives, such as changing production process, and investing in energy-saving projects, with the reference to above mentioned 3 companies.

Table 2. Income and Asset figures extracted from 2013 Annual Reports

\begin{tabular}{|l|l|l|}
\hline Listed Companies & Income before Tax (Million) & Total Assets (Million) \\
\hline HSBC & HK\$144,756 & HK\$6,439,355 \\
\hline CLP & HK\$5,840 & HK $\$ 211,685$ \\
\hline CM & RMB $\$ 158,579$ & RMB $\$ 1,167,392$ \\
\hline
\end{tabular}

In fact, businesses are running in an information-driven economy where their practices have become increasingly transparent, and all stakeholders have kept eyes on what they are doing. Businesses are under increasing pressure from various stakeholders that they have to demonstrate they get plans and strategies for sustainable development. Therefore, the trend of having CSR practices is unavoidable. 
Although Oxfam Hong Kong has submitted a proposal to the Financial Services and Treasury Bureau of the Hong Kong Government on rewriting the Companies Ordinance requesting companies more CSR disclosure, the 2014 New Companies Ordinance's major initiatives focus on financial aspects only like share capital, amalgamation, directors and officers, financial statements, auditor's rights, and company administration (PWC, 2014). The Hong Kong Government should include CSR requirements in Companies Ordinance in order to encourage companies to be more socially responsible, such as disclosure on environmental and social issues, providing incentives for companies doing CSR especially support for small and medium-sized companies. Incentives could be in form of tax deduction, government subsidy to companies in providing CSR training to employees or developing energy-saving products or adopting energy-renewable production process.

\section{Limitations and Future Research}

This study mainly uses secondary data for analysis. In future, questionnaire or interviews can be conducted with the companies and public to collect primary data for analysis. Besides, this study adopts the 2009 survey result of Oxfam Hong Kong in selecting the 3 companies for analysis. The ranking of these 3 companies may be different year from year. Future study can select companies from more recent survey result if available. Then the comparison of their current financial results will be more relevant.

\section{References}

Bebbington J., Larrinage C., \& Moneva J.M. (2008). Corporate social reporting and reputation risk management. Accounting, Auditing and Accountability Journal, 21(3), 337-361. http://dx.doi.org/10.1108/09513570810863932

Christensen L.J., Peirce E., Hartman L.P., Hoffman W.M., \& Carrier J. (2007). Ethics, CSR, and Sustainability Education in the Financial Times Top 50 Global Business Schools: Baseline Data and Future Research Directions. Journal of Business Ethics, 73(4), 347-368. http://dx.doi.org/10.1007/s10551-006-9211-5

CLP. (2013). 2013Annual Report, China Light Power Holdings Limited.

CLP. (2013). 2013Sustainability Report, China Light Power Holdings Limited.

CM. (2013). 2013 Annual Report, China Mobile Limited.

CM. (2013). 2013Sustainability Report, China Mobile Limited.

Cruz L.B., \& Boehe D.M. (2008). CSR in the global marketplace: towards sustainable global value chains. Management Decision, 46(8), 1187-1209. http://dx.doi.org/10.1108/00251740810901381

CSR Japan website, http://www.csr-weltweit.de/en/laenderprofile/profil/japan/index.html.

Danish Government Centre. (2011). Statutory requirements on reporting CSR. www.csrgov.dk/sw51190.asp. 
Doukakis I.P., Kapardis M.K., \& Katsioloudes M. (2005). Corporate social responsibility: the way forward? Maybe not! A preliminary study in Cyprus. European Business Review, 17(3), 263-279. http://dx.doi.org/10.1108/09555340510596661

Freeman R.E. (1984). Strategic Management: a Stakeholder Approach, Pitman Publishing, Boston, MA.

Friedman M. (1962). Capitalism and Freedom, University of Chicago Press, Chicago, IL.

Ghillyer A. (2014). Business Ethics Now, $4^{\text {th }}$ edition,McGraw-Hill Education, New York.

Gyves S., and Higgins E.O. (2008). Corporate social responsibility: an avenue for sustainable benefit for society and the firm? Society and Business Review, 3(3), 207-223. http://dx.doi.org/10.1108/17465680810907297

Hoffman R.C. (2007). Corporate social responsibility in the 1920s: an institutional perspective. Journal of Management History, 13(1), 55-73. (http://dx.doi.org/10.1108/17511340710715179)

Holme C. (2010). Corporate social responsibility: a strategic issue or a wasteful distraction?.Industry and Commercial Training, 42(4), 179-185. (http://dx.doi.org/10.1108/00197851011048528)

HSBC. (2013). 2013Annual Report, Hong Kong \& Shanghai Banking Corporation.

HSBC. (2013). 2013Sustainability Report, Hong Kong \& Shanghai Banking Corporation.

Lance M. (2001). What do we mean by corporate social responsibility?.Corporate Governance, 1(2), 16-22.

Lanoizelee F.Q. (2011). Are competition and corporate social responsibility compatible? -The myth of sustainable competitive advantage. Society and Business Review, 6(1), 77-98. http://dx.doi.org/10.1108/17465681111105850

Mandhachitara R., \& Poolthong Y. (2011). A model of customer loyalty and corporate social responsibility. Journal of Services Marketing, 25(2), 122-133. http://dx.doi.org/10.1108/08876041111119840

McWilliams A., \& Siegel D. (2001). Corporate Social Responsibility: a theory of the firm perspective. Academy of Management Review, 26(1), 117-127.

OHK (2010). Submission to the Financial Services and Treasury Bureau of the Hong Kong SAR Government on the Rewrite of the Companies Ordinance. Oxfam Hong Kong.

Olivia (2011). Difference between business ethics and social responsibility. Jan $24^{\text {th }} 2011$, (www.differencebetween.com/difference-between-business-ethics-and-social-responsibilty/).

PWC (2014). Hong Kong preparing for the New Companies Ordinance. PricewaterhouseCoopers Limited, 2014 (www.pwchk.com).

Yeoh P. (2007). The direction and control of corporations: law or strategy?.Managerial Law, 49(1/2), 37-47. 